\title{
Existence of synchronization of reproduction at the level of the social group of the European wild boar (Sus scrofa)*
}

\author{
Isabelle Delcroix, R. Mauget and J. P. Signoret $\uparrow$ \\ C. N. R. S. Centre d'Etudes Biologiques des Animaux Sauvages, Forêt de Chizé, \\ F-79360 Beauvoir/Niort, France; and $+I$. N. R. A. Laboratoire de Comportement Animal, \\ F-37380 Nouzilly, France
}

\begin{abstract}
Summary. Reproductive events were recorded in two groups of female wild boars kept in semi natural conditions. The first group had been kept for 2 consecutive years with a male. Most farrowing took place within 4-5 days: $6 / 7$ in the first year and $8 / 9$ for the second. A second group of 5 females was kept for 13 months in the absence of a male, and oestrous cycles were monitored by weekly measurement of plasma progesterone concentrations. All the females experienced summer-autumn anoestrus and resumed cycling in the same week of December. This accurate synchronization of reproduction may result from stimulation amongst females belonging to the same social unit.
\end{abstract}

Keywords: reproduction; synchronization of oestrus; social group; wild boar

\section{Introduction}

In European wild boars having no history of hybridization with domesticated pigs, reproduction is clearly seasonal, with anoestrus (ovarian inactivity) occurring during the summer and early autumn (Mauget, 1982). Farrowing occurs in spring but ranges from late winter (February) to late summer (September). As in most wild species (Mauget et al., 1981), photoperiodism appears to be the critical environmental factor involved in the seasonality of breeding, although food availability could account for minor year-to-year variations.

However, other environmental factors have been observed to influence the timing of reproduction. Synchronization of oestrous behaviour has been reported for several wild or domestic species as a consequence of socio-sexual interactions. The stimuli involved appear to be mainly of an olfactory nature, frequently originating from the male (Keverne, 1983; Vandenbergh, 1988). In the wild pig, field observations suggest that even when births are spread over several months for the whole population, a close synchronization of reproduction could occur within each social group constituted by the permanent association of a small number of females (Meynhardt, 1978; Mauget, 1980). To verify these observations, we observed in a long-term experiment the timing of reproduction in groups of wild female pigs kept in large forest paddocks. Data on reproductive behaviour were recorded during 2 years for a group of adult females penned in the presence of a male. Furthermore, ovarian activity was monitored throughout the year in another group composed of mature females kept without a male.

\section{Materials and Methods}

The study took place in the Chizé Forest National Reservation Area (midwestern France: $46^{\circ} 08^{\prime} \mathrm{N}, 0^{\circ} 24^{\prime} \mathrm{W}$ ).

Two groups of pure wild boars were kept in forest enclosures $\left(1-2 \mathrm{ha}, 1-2 \times 10^{2} \mathrm{~m}^{2}\right)$ under natural climatic conditions. They received a commercial diet $(\sim 1.5 \mathrm{~kg} / \mathrm{animal}$ per day $)$ in addition to the natural food. No domestic pig was kept within several kilometres of the reservation area.

${ }^{*}$ Reprint requests to Dr R. Mauget. 


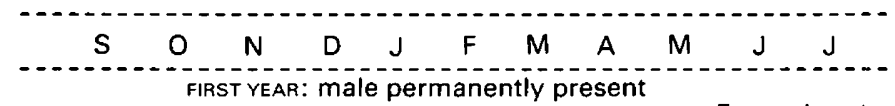

Farrowing date

\begin{tabular}{|c|c|c|c|}
\hline Female A & _anoestrus & $-\cdots$ & 7-8 June \\
\hline Female C & _anoestrus & $\ldots$ & 7-8 June \\
\hline Female B & anoestrus & pregnancy & 10-11 June \\
\hline Female D & _anoestrus & pregnancy & 10-11 June \\
\hline Female E & _anoestrus & pregnancy & 10-11 June \\
\hline Female F & _anoestrus & pregnancy & 10-11 June \\
\hline Female a & _immaturit & pregnancy & \\
\hline
\end{tabular}

SECOND YEAR: introduction of a new male in late October

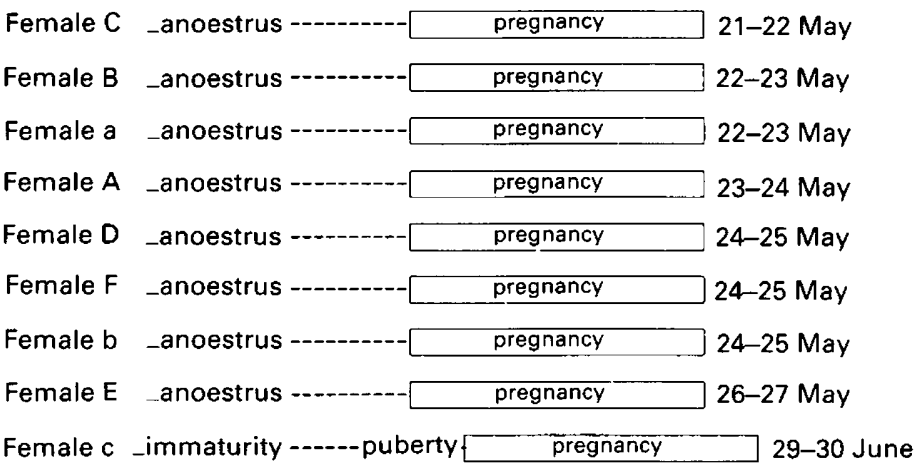

Fig. 1. Timing of the reproductive events for a social group of adult females reared in the presence of a male.

A first group of 6 adult females ( $>50 \mathrm{~kg}$ body weight) and 4 juveniles was observed for 2 successive years. At the expected time of parturition, the social interactions were observed daily from a hide. Neither capture nor manipulation of the animals was done, and care was taken to avoid stress resulting from human interference. At the beginning of the experiment, an adult male had already been present for 1 year. After the first observed period of parturition it was removed (on 1 October) and replaced by another adult male (on 23 October) late in the anoestrous season, but before the onset of the next season of mating.

Another group of 5 adult females, kept in an enclosure for 1 year and having not farrowed, was maintained for 1 more year without a male. They were captured each week for 13 months and blood samples were withdrawn by radial venepuncture. After centrifugation within $1 \mathrm{~h}$ of collection, plasma was collected and stored at $-20^{\circ} \mathrm{C}$. Plasma concentrations of progesterone were evaluated by radioimmunoassay using a progesterone RIA kit (Biomérieux Lab., F69752 Marcy-l'Etoile, France) to monitor oestrous cycles by assessing corpus luteum function. Validation tests have been reported previously for wild boar plasma (Mauget, 1980). Average recovery of progesterone was $90 \%$ and the average intra- and inter-assay CVs were 2.3 and $3.0 \%(n=13)$, respectively. Assay sensitivity, defined as $90 \%$ of total binding, was $100 \mathrm{pg} / \mathrm{ml}$ plasma. This study took place during a year different from that for the group of females kept with a male. 

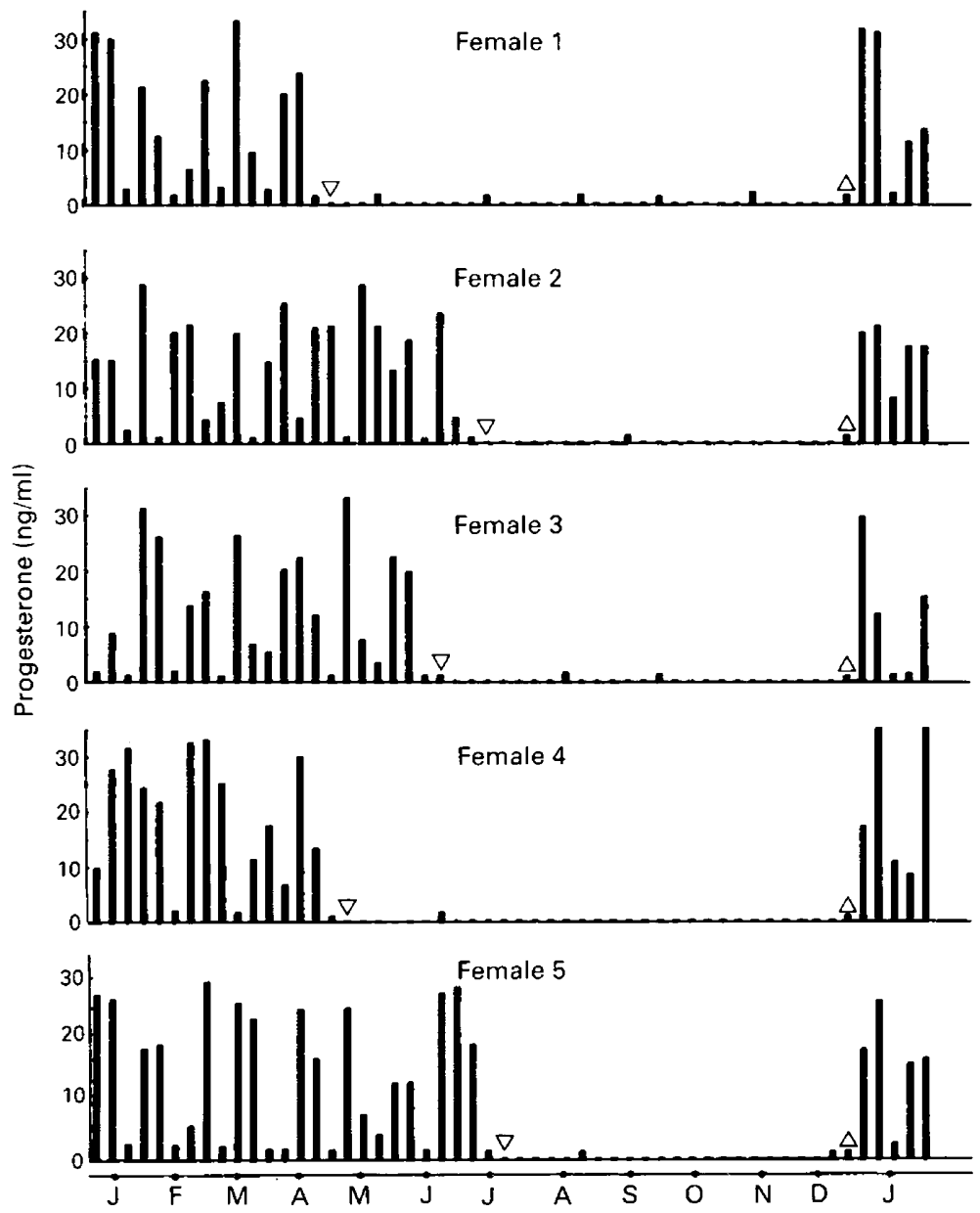

Fig. 2. Ovarian activity throughout 1 year in a group of mature females kept without a male, indicating cessation $(\nabla)$ and onset $(\triangle)$ of cyclic ovarian activity.

\section{Results}

\section{Reproduction in a social group in the presence of a male}

Daily observations enabled the day of farrowing for each female of the group to be recorded (Fig. 1). During the first year, the 6 adult females farrowed between 7 and 11 June. This was a consequence of the close synchronization in the onset of cyclic ovarian activity within a few days. Only one of the juvenile females reached puberty during the first year (in March, at 11 months of age) and farrowed at the end of July.

During the second year, the farrowing period for the 6 adult and 2 young females was again limited to a few days, from 21 to 27 May. Only one of the young females was not synchronized and farrowed 1 month later (end of June). The onset of ovarian activity of all the females took place within the last week of January, i.e. several months after the removal of the first male and the introduction of the second. 


\section{Ovarian cyclicity in a social group without male}

Figure 2 presents the individual profiles of plasma progesterone measured in the 5 females of the group kept during 1 year without a male. Individual variations appear for the moment of cessation of cyclic ovarian activity, ranging from mid-April to July. However, after a period of anoestrus of several months, all the females exhibited an elevated concentration of progesterone during the same week, indicating a close synchronization between individuals in the onset of ovarian activity.

\section{Discussion}

As already described (Mauget, 1980), the first oestrus of the breeding season takes place at different times in different years, according to natural food availability and other environmental and climatic factors. The results of the present study show an accurate synchronization in the reproductive processes within the social group of female wild pigs, irrespective of the time of reproduction.

Although descriptive, such a study raises the question of the mechanisms involved. In most of the cases cited in the literature, the synchronization of oestrous cycles results from a male effect. First described in laboratory rodents (Whitten, 1956), this has been observed in several other species. In female sheep and goats, the introduction of the male into a group of previously isolated anoestrous females results in synchronized oestrus (Underwood et al., 1944; Shelton, 1960). In domestic cattle, the presence of the male induces an earlier occurrence of puberty (Izard \& Vandenbergh, 1982) and of post-partum oestrus (Zalesky et al., 1984). In the female domestic pig, factors of social environment have been reported to influence reproduction (Hemsworth, 1982). The process of puberty is accelerated in the presence of the male (Brooks \& Cole, 1970; Hughes, 1982), as is the occurrence of post-partum ovulation (Walton, 1986). However, the presence of the male acting as the only effective stimulus to induce oestrus in the prepubertal female pig is not established: the changes in the environment could be similarly efficient even in the absence of the male (du Mesnil du Buisson \& Signoret, 1962; Wodzicka-Tomaszewska et al., 1985).

The present results show that ovarian activity is as accurately synchronized in the absence as in the presence of the male. Consequently, such a synchronization appears more likely to be a consequence of interactions between females. Similar observations have been made for dogs (Naaktgeboren \& van Straalen, 1983) and red deer (Iason \& Guinness, 1985). In man, McClintock (1971), and Russell et al. (1980) have established the role of pheromones. In the laboratory mouse, grouping females has been observed to exert an inhibitory effect on ovarian activity (Champlin, 1971), while for other mammalian species there is a stimulatory effect in grouped females. The most complete work has been done for the laboratory rat (McClintock, 1978, 1983), showing that synchronization of oestrus in cyclic females was due to pheromonal communication.

The extremely accurate timing of reproduction at the level of the social unit is likely to have a functional significance due to the favourable consequences resulting from the homogeneity of the group, for instance in allowing more efficient protection of the neonates.

\section{References}

Brooks, P.H. \& Cole, D.J.A. (1970) Effect of presence of a boar on attainment of puberty in gilts. $J$. Reprod. Fert. 23, 435-440.

Champlin, A.K. (1971) Suppression of oestrus in grouped mice: effect of various densities and the possible nature of stimulus. $J$. Reprod. Fert. 27, 233-241.

du Mesnil du Buisson, F. \& Signoret, J.P. (1962) Influence des facteurs externes sur le déclenchement de la puberté chez la truie. Annls Zootech. 11, 53-59.

Hemsworth, P.H. (1982) Social environment and reproduction. In Control of Pig Reproduction, pp. 585-601.
Eds D. J. A. Cole \& G. R. Foxcroft. Butterworth Scientific, London.

Hughes, P.H. (1982) Factors affecting the natural attainment of puberty in the gilt. In Control of Pig Reproduction, 117-138. Eds D. J. A. Cole \& G. R. Foxcroft. Butterworth Scientific London.

Iason, G.R. \& Guinness, F.E. (1985) Synchrony of oestrus and conception in red deer (Cervus elaphus L.). Anim. Behav. 33, 1169-1174.

Izard, M.K. \& Vandenbergh, J.G. (1982) The effects of bull urine on puberty and calving date in crossbred beef heifers. J. Anim. Sci. 55, 1160-1168.

Downloaded from Bioscientifica.com at $04 / 26 / 2023$ 09:45:27AM 
Keverne, E.B. (1983) Pheromonal influences on the endocrine regulation of reproduction. Trends Neurosci., pp. $381-384$.

Mauget, R. (1980) Régulations écologiques, comportementales et physiologiques (fonction de reproduction), de l'adaptation du Sanglier, Sus scrofa L., au milieu. Thèse d'Etat Université François-Rabelais, Tours.

Mauget, R. (1982) Seasonality of reproduction in the wild boar. In Control of Pig Reproduction, pp. 509526. Eds D. J. A. Cole \& G. R. Foxcroft. Butterworth Scientific, London.

Mauget, R., Boissin-Agasse, L. \& Boissin, J. (1981) Ecorégulation du cycle de la fonction de reproduction chez les mammifères sauvages. Bull. Soc. Zool. Fr. 106, 431-443.

McClintock, M.K. (1971) Menstrual synchronism and suppression. Nature, Lond. 229, 244-245.

MeClintock, M.K. (1978) Oestrous synchronism in the rat and its mediation by airborne chemical communication. Horm. \& Behav. 10, 264-276.

McClintock, M.K. (1983) Modulation of the oestrous cycle by pheromones from pregnant and lactating rats. Biol. Reprod. 28, 823-829.

Meynhardt, H. (1978) Schwarzwild report. Neumann Verlag Leipzig Radebeul. 205 pp.

Naaktgeboren, C. \& van Straalen, J.G. (1983) On the influence of environmental factors on heat in the bitch. Z. Tierzücht. Züchtbiol. 100, 5, 321-337.

Russell, M.J., Switz, G.M. \& Thompson, K. (1980) Olfactory influences on human menstrual cycle. Pharmacol. Biochem. Behav. 13, 737-738.
Shelton, M. (1960) Influence of the presence of a male goat on the initiation of estrous cycling and ovulation of Angora does. J. Anim. Sci. 19, 368-375.

Underwood, E.J., Shier, F.L. \& Davenport, N. (1944) Studies in sheep industry in W.A. V. The breeding season of merino, crossbred and British breeds in the agricultural districts. J. Agric. West. Aust. 11, 135-143.

Vandenbergh, J.G. (1988) Pheromones and mammalian reproduction. In The Physiology of Reproduction, pp. 1679-1696. Eds E. Knobil \& J. D. Neill. Raven Press, New York.

Walton, J.S. (1986) Effect of boar presence before and after weaning on estrus and ovulation in sows. $J$. Anim. Sci. 62, 9-15.

Whitten, W.K. (1956) Modifications of the oestrous cycle of the mouse by external stimuli associated with the male. J. Endocr. 13, 399-400.

Wodzicka-Tomaszewska, M., Martinat-Botté, F. Prunier, A. \& Signoret, J.P. (1985) Effets respectifs de la mise en présence du mâle et du stress sur le déclenchement de la puberté de la jeune truie. Essais préliminaires. $J$. Rech. Porcine en France 17, 139-146.

Zalesky, D.D., Day, M.L., Garcia-Winder, M., Imakawa, K., Kittok, R.J., D'Occhio, M.J. \& Kinder, J.E. (1984) Influence of exposure to bulls on resumption of estrous cycles following parturition in beef cows. $J$. Anim. Sci. 59, 1135-1139.

Received 6 November 1989 